\title{
Proposal of methodology for analysis of stress level based on EEG signals
}

\author{
Alexandre Pomer-Escher ${ }^{1 *}$, Teodiano Bastos-Filho ${ }^{2}$, Maria Dolores Souza ${ }^{3}$ \\ From 5th Congress of the Brazilian Biotechnology Society (SBBIOTEC) \\ Florianópolis, Brazil. 10-14 November 2013
}

Stress can affect all people, regardless of age, gender or ethnicity. The human body utilizes stress as a response in three different situations, classified according to the way it generates physical, mental or emotional stress. It is important to notice that the nervous system evokes the same physiological responses, no matter what type of stress, and those responses cause a change of level in physical and cognitive performance. This paper presents an analysis methodology of the stress level using brain's signals captured by Electroencephalogram (EEG).

Professionals from Vitoria's Fire Department, members of Projeto VIDA participate as volunteers. The EEG signals are captured through a cap placed over the volunteer's head in order to capture the brain's signals, using electrodes specifically placed in the frontal cortex at positions Fp1, Fp2, F3 and F4. The results are analyzed together with the peripheral physiological signals, such as: heart beat rate (ECG), peripheral blood flow (at fingers and toes), skin conductance, breath rate and body temperature. A validation study is conducted through a comparison of data available in literature, as well as with evaluation conducted by a psychologist.

The results are analyzed in order to get a correlation between EEG signals and physical mental or emotional stress.

\begin{abstract}
Authors' details
'Post-Graduate Program in Biotechnology, Federal University of Espirito Santo, Vitoria, Espirito Santo, 29650000, Brazil. ${ }^{2}$ Post-Graduate Program in Electrical Engineering, Federal University of Espirito Santo, Vitória, spirito Santo, 29075910, Brazil. ${ }^{3}$ Post-Graduate Program in Psychology, Federal University of Espirito Santo, Vitória, Espirito Santo, 29075910, Brazil.
\end{abstract}

Published: 1 October 2014

'Post-Graduate Program in Biotechnology, Federal University of Espirito Santo, Vitoria, Espirito Santo, 29650000, Brazil

Full list of author information is available at the end of the article

\section{References}

1. Hosseini SA, Khalilzadeh MA: Emotional Stress Recognition System Using EEG and Psychophysiological Signals: Using New Labelling Process of EEG Signals in Emotional Stress State. International Conference on Biomedical Engineering and Computer Science (ICBECS); 2010, 1-6, doi: 10.1109/ICBECS.2010.5462520.

2. Phan KL, Wager T, Taylor SF, Liberzon I: Functonal neuroanatomy of emotion, a meta-analysis of emotion activation studies in PET and fMRI. Neuroimage 2002, 16(2):331-348.

3. Reisman S: Measurement of physiological stress. Bioengineering Conference, 1997. Proceedings of the IEEE 1997 23rd Northeast 21-23, 21-22 May 1997 doi: 10.1109/NEBC.1997.594939.

4. Lewis M, Haviland-Jones JM, Barrett LF: Handbook of Emotions. New York: Guilford Press; 32010.

5. Molavi M, Bin Yunus J, Akbari E: Comparison of Different Methods for Emotion Classification. Modelling Symposium (AMS) Sixth Asia; 2012, 50-53, 29-31 May 2012 doi: 10.1109/AMS.2012.53.

doi:10.1186/1753-6561-8-S4-P62

Cite this article as: Pomer-Escher et al.: Proposal of methodology for analysis of stress level based on EEG signals. BMC Proceedings 2014 8(Suppl 4):P62.
Submit your next manuscript to BioMed Central and take full advantage of:

- Convenient online submission

- Thorough peer review

- No space constraints or color figure charges

- Immediate publication on acceptance

- Inclusion in PubMed, CAS, Scopus and Google Scholar

- Research which is freely available for redistribution

Submit your manuscript at www.biomedcentral.com/submit
() Biomed Central 